\title{
Review
}

\section{Pathogenesis of prion diseases: a progress report}

\author{
A Aguzzi ${ }^{\star 1}$ and FL Heppner ${ }^{1}$ \\ ${ }^{1}$ Institute of Neuropathology, Department of Pathology, Schmelzbergstrasse. \\ 12, University Hospital Zurich, $\mathrm{CH}-8091$ Zurich, Switzerland \\ * Corresponding author: A Aguzzi, Institute of Neuropathology, \\ Schmelzbergstrasse 12, University Hospital, $\mathrm{CH}-8091$ Zürich. \\ Tel: +411 255 2107; Fax: +411255 4402; E-mail: adriano@pathol.unizh.ch
}

Received 17.5.00; revised 28.6.00; accepted 6.7.00

Edited by G Melino

\begin{abstract}
Almost 20 years have passed since Stanley Prusiner proposed that the agent causing transmissible spongiform encephalopathies consists exclusively of a protein and termed it prion. A mixed balance can be drawn from the enormous research efforts that have gone into prion research during this time. On the negative side, the protein-only hypothesis has not been conclusively proven yet. On the positive side, our understanding of spongiform encephalopathies has experienced tremendous advances, mostly through human genetics, mouse transgenetics, and biophysical methods. Perhaps the most astonishing development is the realization that many human neurodegenerative diseases for which transmissibility has been more or less stringently excluded, may follow pathogenetic principles similar to those of prion diseases. Also, the hypothesis that prion-like phenomena may underlie certain non-genetic traits observed in yeast has resulted in the surprising recognition that the instructional self-propagating changes in protein conformation may be much more prevalent in nature than previously thought. The latter developments have been astonishingly successful, and one could now argue that the prion principle is much more solidly established in yeast than in mammals. Cell Death and Differentiation (2000) 7 , $889-902$.
\end{abstract}

Keywords: prion protein; $\mathrm{PrP}^{\mathrm{Sc}}$; $\mathrm{PrP}^{\mathrm{C}}$; transmissible spongiform encephalopathies; scrapie; protein-only hypothesis

Abbreviations: $\mathrm{PrP}^{\mathrm{C}}$, cellular prion protein; $\mathrm{PrP}^{\mathrm{Sc}}$, scrapieassociated prion protein; BSE, bovine spongiform encephalopathy; CJD, Creutzfeldt-Jakob disease; nvCJD, new variant form of Creutzfeldt-Jakob disease; TSE, transmissible spongiform encephalopathy; Dpl, Doppel; MBM, meat and bone meal;

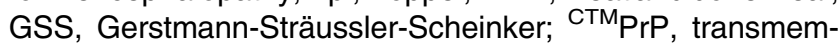
brane form of the prion protein; FDC, follicular dendritic cell; PS, pentosan polysulphate; PcTS, phtalocyanine tetrasulfonate; iPrP13, 13-residue $\beta$-sheetbreaker peptide; PrD, prion-forming domain

\section{Introduction}

The prion was defined in 1992 by Stanley B Prusiner as the infectious agent that causes transmissible spongiform encephalopathies (TSEs), or prion diseases. According to Prusiner, the prion (from proteinaceous infectious only) is devoid of informational nucleic acids ${ }^{1}$ and consists of an 'infectious' protein that is capable of converting a normal host protein termed $\mathrm{PrP}^{\mathrm{C}}$ (celluar prion protein), or simply PrP, into a likeness of itself. This hypothesis is now very widely accepted, although critique continues to be voiced mainly because no direct and incontrovertible evidence has been forthcoming yet. ${ }^{2}$ In 1982 Prusiner isolated a protease- and heat-resistant protein from the brain of scrapie-infected hamsters. ${ }^{3}$ He termed it $\mathrm{PrP}^{\mathrm{Sc}}$ (scrapie-associated prion protein) and proposed that $\operatorname{PrP}^{S c}$ is identical with the infectious agent. The gene which encodes $\operatorname{PrP}^{\mathrm{c}}, \operatorname{Prnp}$, was identified later by Charles Weissmann at the Institute of Molecular Biology in Zurich ${ }^{4}$ in hamsters, and independently by Bruce Chesebro in mice. ${ }^{5}$ Prnp is active in brain and many other cells of the body in both prion-infected and non-infected animals and, most strikingly, removal of Prnp from the mouse genome does not prevent normal development yet leads to complete immunity from scrapie. ${ }^{6-8}$

The only organ system in which severe histopathological damage can be demonstrated as a consequence of infection with prions is the nervous system. This applies to all human TSEs, such as Creutzfeldt-Jakob disease, Gerstmann-Sträussler-Scheinker Syndrome, Kuru and fatal familial insomnia, and to all known prion encephalopathies of animals, as summarized in Table 1 . However, it is apparent that prions can colonize organs other than the central and peripheral nervous system, and can be demonstrated in extracerebral compartments, and fibrosis and weight reduction is often seen in spleens of terminally scrapie-sick mice.

While the prototype of all prion diseases, scrapie in sheep, has been known for more than two centuries, bovine spongiform encephalopathy (BSE) had its first recognition in 1986 and developed into an epizootic phenomenon. The emergence of a new variant form of Creutzfeldt-Jakob disease (nvCJD) in young people in the UK has raised the possibility that BSE has spread to humans by dietary exposure..$^{9-12}$ Experimental evidence claiming that the agent causing BSE is indistinguishable from the nvCJD agent supports this view, ${ }^{13}$ although no ultimate proof has been presented, due to limitations of the analytical assays used for determining the characteristics of prions. Although most cases of human prion diseases are sporadic, about $10 \%$ are familial and linked to one of a number of mutations in the gene encoding PrP. It is believed that these mutations allow spontaneous conversion of $\operatorname{PrP}^{\mathrm{C}}$ into $\operatorname{PrP}^{\mathrm{Sc}}$ with a frequency sufficient to cause disease within the lifetime of an individual. ${ }^{14}$ 
Table 1 The prion diseases

\begin{tabular}{|c|c|c|}
\hline Disease & Host & Mechanism of pathogenesis \\
\hline iCJD & humans & infection from priorn-contaminated hGH, dura mater grafts, etc. \\
\hline nvCJD & humans & infection from BSE prions (hyphothesized) \\
\hline fCJD & humans & germ-line mutations in PRNP gene \\
\hline sCJD & humans & $\begin{array}{l}\text { somatic mutation resulting in spontaneous conversion of } \mathrm{PrP}^{\mathrm{C}} \text { into } \\
\mathrm{PrP}^{\mathrm{Sc}} \text { ? }\end{array}$ \\
\hline Kuru & fore people & infection through ritualistic cannibalism \\
\hline GSS & humans & germ-line mutations in $P R N P$ gene \\
\hline FFI & humans & germ-line mutations in PRNP gene \\
\hline FSI & humans & $\begin{array}{l}\text { somatic mutation resulting in spontaneous conversion of } \mathrm{PrP}^{\mathrm{C}} \text { into } \\
\mathrm{PrP}^{\mathrm{Sc}} \text { ? }\end{array}$ \\
\hline Scrapie & sheep & infection in genetically susceptible sheep \\
\hline BSE & cattle & infection with prion-contaminated MBM \\
\hline TME & $\operatorname{mink}$ & infection with prions from sheep or cattle \\
\hline CWD & mule, deer, elk & Unknown \\
\hline FSE & cats & infection with prion-contaminated bovine tissues or MBM \\
\hline Exotic ungulate encephalopathy & greater kudu, nyala, oryx & infection with prion-contaminated MBM \\
\hline
\end{tabular}

iCJD, iatrogenic CJD; nvCJD, new variant CJD; fCJD, familial CJD; sCJD, sporadic CJD; GSS, Gerstmann-Sträussler-Scheinker disease; FFI, fatal familial insomnia; FSI, fatal sporadic insomnia; BSE, bovine spongiform encephalopathy ('mad cow disease'); TME, transmissible mink encephalopathy; CWD, chronic wasting disease; FSE, feline spongiform encephalopathy; hGH, human growth hormone; MBM, meat and bone meal

\section{Prion diseases - a brief history}

Although scrapie in sheep has been known for at least 250 years, only with discovery of transmissibility in the 1930s were the unusual properties of the infectious agents recognized. In particular the long incubation time and resistance to conventional sterilization procedures. ${ }^{15}$ About 30 years later, Griffith outlined the 'protein-only' hypothesis ${ }^{16}$ that has gained widespread recognition and acceptance after Stanley B Prusiner purified the pathological protein $\mathrm{PrP}^{\mathrm{Sc}}$ in $1982 .^{3}$

When transmission of scrapie in sheep was described, the high incidence of familial Creutzfeldt-Jakob disease (fCJD) in some families had already been recognized. Some 20 years later, transmissibility of Kuru, a disease of New Guinea highlanders provoked through ritualistic cannabalism, and of CJD to apes could be demonstrated. ${ }^{17,18}$ Epidemiological studies designed to identify the source of the CJD infection evidenced geographic clusters: Libyan Jews living in Israel developed CJD about 30 times more frequently than other Israelis: ${ }^{19}$ while this was first thought to result from consuming lightly cooked brains from scrapie-infected sheep prior to emigration to Israel, it was subsequently shown that the Libyan Jewish patients carry a mutation at codon 200 (E200K) in PRNP, the gene encoding $\operatorname{PrP}^{20}$

In 1986, a novel type of TSE was found to affect cows: bovine spongiform encephalopathy (BSE) or 'mad cow disease'.21 Most likely it has been transmitted to cows through feeding with rendered offal derived from meat and bones of scrapie-infected sheep - and presumably from BSE-infected cows to humans causing new variant CJD (nvCJD).

\section{The 'protein-only' hypothesis}

Although the exact physical nature of the transmissible agent is still controversial, a very large body of experimental data supports the 'protein only' hypothesis, first outlined in general terms by Griffith in $1967^{16}$ and enunciated in its updated and detailed form by Prusiner. ${ }^{3}$ It proposes that the agent is devoid of nucleic acid and consists solely of an abnormal conformer of the cellular prion protein, $\mathrm{PrP}^{\mathrm{C}}$. Additional evidence is provided by very recent findings demonstrating that mouse PrP expressed in both yeast and neuronal tumor cells can be converted into an abnormal form close to that adopted by naturally occurring mouse prions. Whether these transgenetically produced prions can infect mice under virus-free conditions has not been determined beyond any doubt: some reports have implied such de novo generation of prions, ${ }^{22}$ but others appear to have yielded different results. ${ }^{23}$ If positive, such experiments may fully prove the 'protein-only' hypothesis and convince skeptics still favoring an as-yetunidentified agent (be it virus, virino, or one of the more exotic microbes which are periodically invoked as the possible cause of TSEs) that may team up with the prion protein to cause disease.

\section{The prion conversion reaction}

Accumulation of an abnormal isoform $\left(\mathrm{PrP}^{\mathrm{Sc}}\right)$ of the host encoded $\mathrm{PrP}^{\mathrm{C}}$ in the central nervous system is a hallmark of prion diseases. Because no chemical differences were found between $\mathrm{PrP}^{\mathrm{C}}$ and $\mathrm{PrP}^{\mathrm{Sc}}$, the two species are believed to differ in their conformation. The 3D structure of $\mathrm{PrP}^{\mathrm{C}}$ has been determined: ${ }^{24-27}$ this has allowed for interesting insights and speculations regarding the mechanism of $\mathrm{PrP}^{\mathrm{Sc}}$ formation in familial spongiform encephalopathies. However, it has never been possible to determine the high-resolution structure of $\mathrm{PrP}^{\mathrm{Sc}}$ : all we know is that the $\beta$-sheet content of $\mathrm{PrP}^{\mathrm{Sc}}$ is much higher $(43 \%)$ than that of $\operatorname{PrP}^{\mathrm{C}}(3 \%){ }^{28}$ Conversion of $\mathrm{PrP}^{\mathrm{C}}$ into $\mathrm{PrP}^{\mathrm{Sc}}$ in prion-infected cells is known to be a later posttranslational process, occurring after $\mathrm{PrP}^{\mathrm{C}}$ has reached its normal extracellular location. In order to explain the mechanism by which a misfolded form of PrP could induce the refolding of 'native', normal $\operatorname{PrP}$ molecules into the abnormal conformation, two distinct models have been postulated: (i) the template assistance or 'refolding' model, and (ii) the nucleation-polymerization or 'seeding' model 
(Figure 1). In the first model, the conformational change is kinetically controlled; a high activation energy barrier prevents spontaneous conversion at detectable rates. Interaction with exogenously introduced $\mathrm{PrP}^{\mathrm{Sc}}$ causes $\mathrm{PrP}^{\mathrm{C}}$ to undergo an induced conformational change to yield $\mathrm{PrP}^{\mathrm{Sc}}$. This reaction may involve extensive unfolding and refolding of the protein to explain the postulated high energy barrier and could be dependent on an enzyme or chaperone, provisionally designated as protein $\mathrm{X}^{29}$ In the second model, $\mathrm{PrP}^{\mathrm{C}}$ and $\mathrm{PrP}^{\mathrm{Sc}}$ are in equilibrium strongly favoring $\mathrm{PrP}^{\mathrm{C}}$. $\mathrm{PrP}^{\mathrm{Sc}}$ is only stabilized when it adds onto a crystal-like aggregate of $\mathrm{PrP} \mathrm{Pc}^{\mathrm{Sc}}$ acting as a seed in nucleation-dependent polymerization process. $^{30}$ Consistent with the latter model, cell-free conversion studies indicate that $\mathrm{PrP}^{\mathrm{Sc}}$ aggregates are able to convert $\operatorname{PrP}^{\mathrm{C}}$ into a protease-resistant $\mathrm{PrP}$ isoform. ${ }^{31-34}$

\section{PrPC and PrPSc}

The cellular prion protein $\mathrm{PrP}^{\mathrm{C}}$ contains two $\mathrm{N}$-linked complex-type oligosaccharides at positions 181 and 197. Accordingly, Western blot analysis of PrP reveals three major bands, reflecting PrP that has two, one, or no glycosylation signals occupied. Glycosylation is important as a signal for correct intracellular trafficking of $\mathrm{PrP}^{\mathrm{C}}$ and possibly also for selective targeting of $\mathrm{PrP}^{\mathrm{Sc}}$ to specific brain regions. ${ }^{35,36}$
Upon translocation of PrP into the endoplasmic reticulum an $\mathrm{NH}_{2}$-terminal secretory signal peptide of 22 amino acids is cleaved from $\mathrm{PrP}$, and $23 \mathrm{COOH}$-terminal residues are processed during addition of the GPI-anchor to the amino acid residue serine 231. Mature mouse PrP contains 209 amino acids. $\mathrm{PrP}^{\mathrm{Sc}}$, which accumulates in TSE-affected organisms is a modified form of $\mathrm{PrP}^{\mathrm{C}}$. $\mathrm{PrP}^{\mathrm{C}}$ and $\mathrm{PrP}^{\mathrm{Sc}}$ have an identical amino acid sequence and share the same posttranslational modifications as assessed by currently available methodology, but differ in their secondary and (presumably) tertiary structure. The physiological isoform $\mathrm{PrP}^{\mathrm{C}}$ is protease-sensitive (consequently sometimes designated as $\mathrm{PrP}^{\mathrm{Sen}}$ ), while the pathological isoform $\mathrm{PrP}^{\mathrm{Sc}}$ is partially protease-resistant (thus also called $\operatorname{PrP}^{\text {res}}$ ). The protease-resistant core of $\mathrm{PrP}^{\mathrm{Sc}}$, designated $\mathrm{PrP}^{27-30}$ according to its molecular weight on SDS-PAGE, provides a specific and reliable molecular marker for the presence of the infectious agent (Figure 2).

Because of its location at the outer surface of cells, anchored by phosphatidylinositol glycolipid, $\operatorname{PrP}$ is a candidate for signaling, cell adhesion or perhaps even for some transport functions. PrP is expressed on many cell types, including neurons, glial cells, and lymphocytes ${ }^{37-39}$ and appears to be developmentally regulated during mouse embryogenesis. ${ }^{40}$ All prion proteins investigated hitherto

a

"Refolding" Model

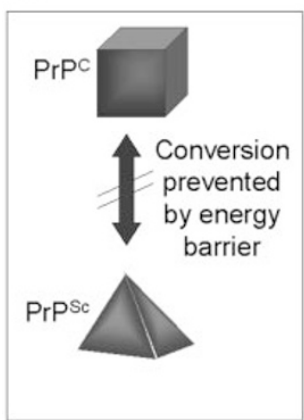

b

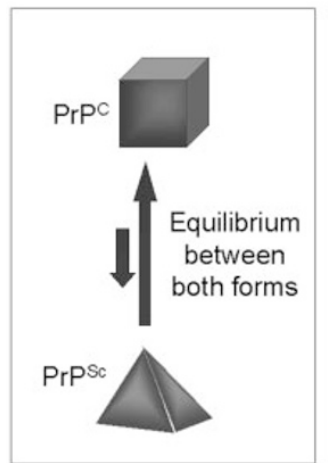

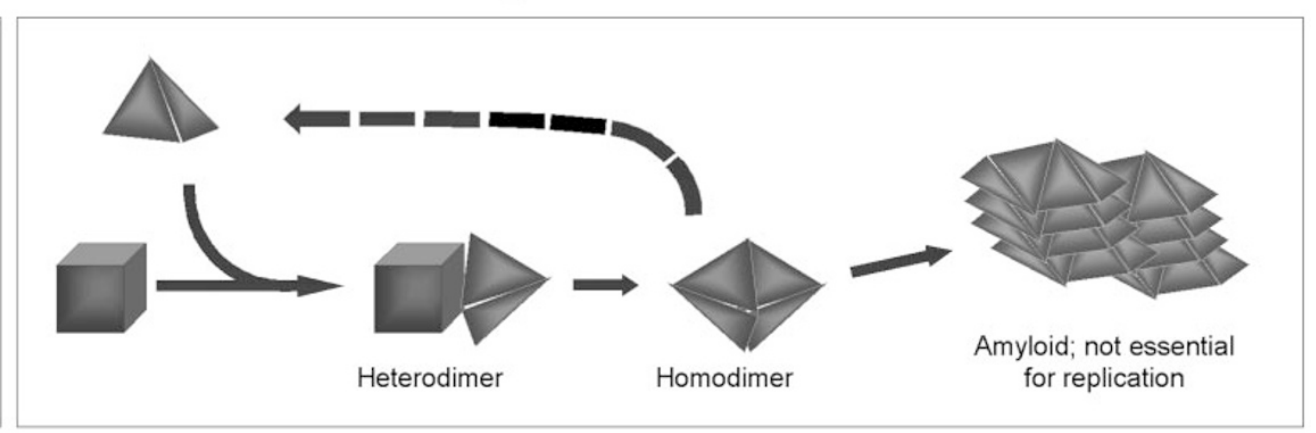

"Seeding" Model

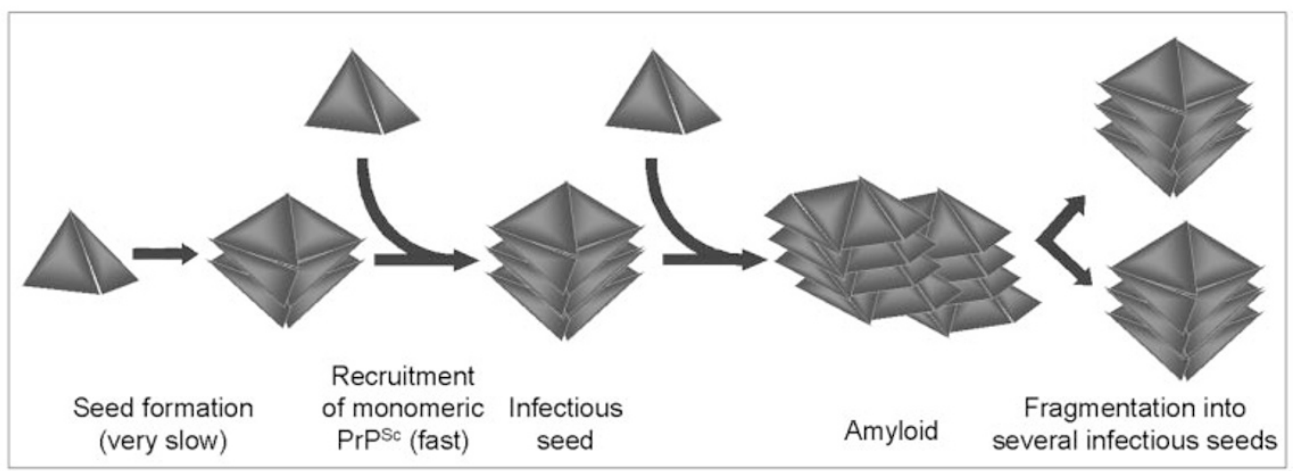

Figure 1 Models for the conformational conversion of $\mathrm{PrP}^{\mathrm{C}}$ into $\mathrm{PrP}^{\mathrm{Sc}}$. (a) The 'refolding' or template assistance model postulates an interaction between exogenously introduced $\mathrm{PrP}^{\mathrm{Sc}}$ and endogenous $\mathrm{PrP}^{\mathrm{C}}$, which is induced to transform itself into further $\mathrm{PrP}^{\mathrm{Sc}}$. A high energy barrier may prevent spontaneous conversion of $\mathrm{PrP}^{\mathrm{C}}$ and $\mathrm{PrP}^{\mathrm{Sc}}$. (b) the 'seeding' or nucleation-polymerization model proposes that $\mathrm{PrPC}^{\mathrm{C}}$ and $\mathrm{PrP}$ (c) are in reversible thermodynamic equilibrium. Only if several monomeric $\mathrm{PrP}^{\mathrm{Sc}}$ molecules are mounted into a highly ordered seed, further monomeric PrP ${ }^{\mathrm{Sc}}$ can be recruited and eventually aggregates to amyloid. Within such a crystal-like seed, $\mathrm{PrP}^{\mathrm{Sc}}$ becomes stabilized. Fragmentation of $\mathrm{PrP}^{\mathrm{Sc}}$ aggregates increases the number of nuclei, which can recruit further $\mathrm{PrP}^{\mathrm{Sc}}$ and thus results in apparent replication of the agent 


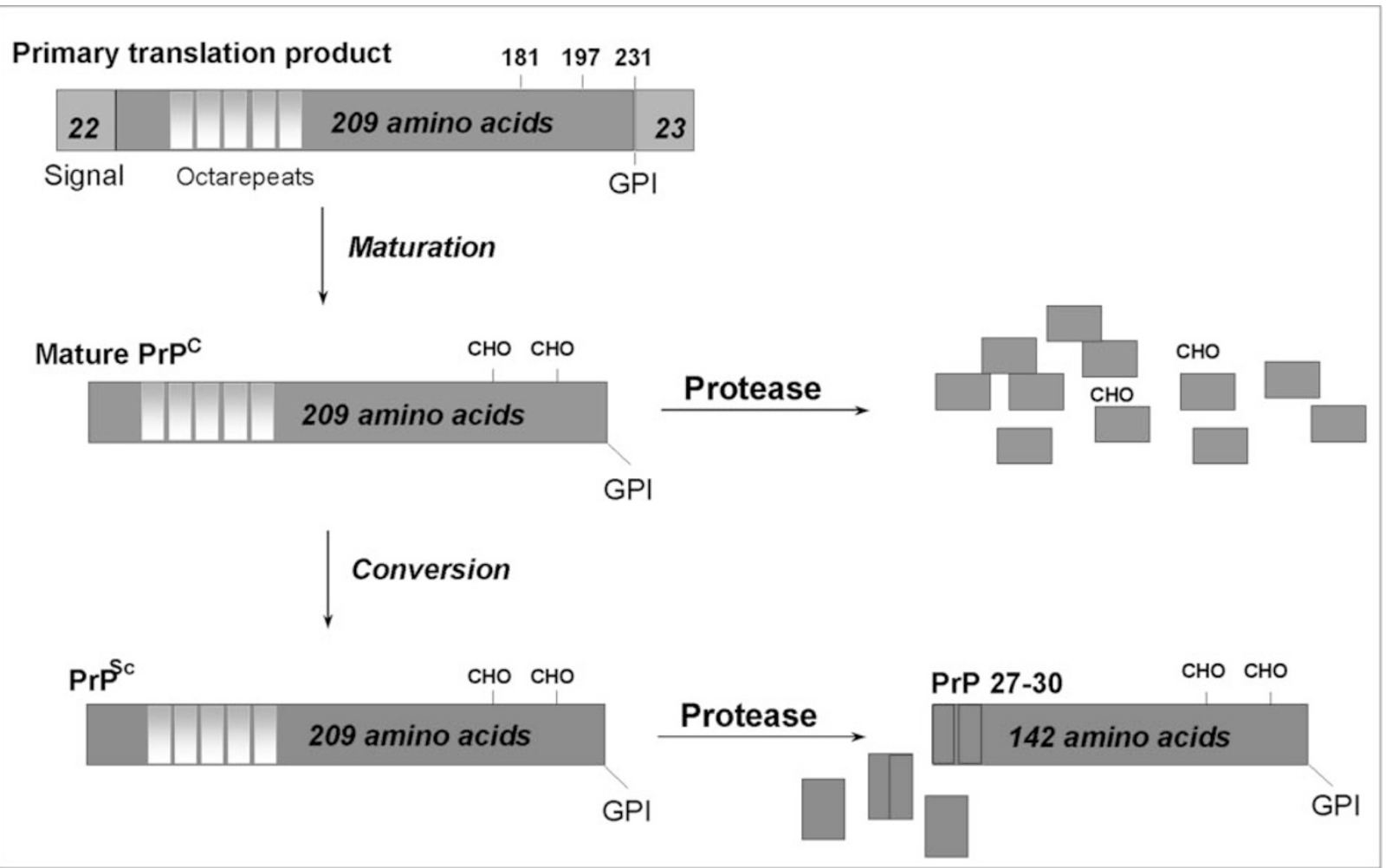

Figure 2 Posttranslational processing of $\mathrm{PrP}^{\mathrm{C}}$. The coding region of the human PrP gene displaying the amino- and carboxy-terminal signal sequences; the five light grey boxes indicate the 'octa repeats', sequences of 8 amino acids. Upon reaching its destination on the cell surface, an amino-terminal secretory signal peptide of 22 amino acids is cleaved from the 254 amino acid $\mathrm{PrP}^{\mathrm{C}}$ precursor protein. Twenty-three carboxy-terminal residues are also processed during addition of the GPI-anchor to a serine residue at position 231. Upon completion of these modifications, mature $\mathrm{PrPC}^{\mathrm{C}}$ contains 209 amino acids. PrPSc is a modified form of $\mathrm{PrP}^{\mathrm{C}}$. PrPC and PrP ${ }^{\mathrm{Sc}}$ have an identical amino acid sequence and share the same posttranslational modifications, but differ in their secondary and (presumably) tertiary structure. The physiological isoform $\mathrm{PrP}^{\mathrm{Sc}}$ is protease-sensitive, while the pathological isoform $\mathrm{PrP}^{\mathrm{Sc}}$ is partially protease-resistant displaying a proteaseresistant core of $\mathrm{PrP}^{\mathrm{Sc}}$, designated $\mathrm{PrP}^{27-30}$

contain four to five 'octa repeats'; repetitive sequences of eight amino acids. ${ }^{41}$ Amplification of the number of octa repeats has been found in hereditary prion diseases such as familial Creutzfeldt-Jakob disease (fCJD) and Gerstmann-Sträussler-Scheinker syndrome. ${ }^{42,43}$ Mammalian and chicken prion octa repeats bind up to four copper atoms. PrP refolded with copper has been shown to have an antioxidant activity similar to that of superoxide dismutase. It has been suggested from studies with peptides based on the octa repeat region of PrP that the four highly conserved histidines in the repeat region coordinate four copper atoms, suggesting that binding of copper may be essential for the function of $\operatorname{PrP}^{\mathrm{C}}{ }^{44}$ Though it remains to be clarified whether the SOD-like activity of the PrP-copper complex is primarily due to an induction of PrP under conditions of oxidative stress involving a binding to copper.

Although PrP is predominantly found in brain tissue, high levels are also present in the heart, skeletal muscle and kidney whereas it is barely detectable in the liver ${ }^{45}$ Several candidate proteins that bind $\operatorname{PrP}^{\mathrm{C}}$ have been reported. Among them are a member of the amyloid precursor protein (APP) family, the amyloid precursor-like protein 1 APLP $1,{ }^{46}$ the $37 \mathrm{kDa}$ human laminin receptor precursor ${ }^{47}$ and an uncharacterized $66-\mathrm{kDa}$ membrane protein. ${ }^{48}$ The observation that PrP binds to APLP1 is intriguing in light of potential analogies of transmissible spongiform encephalopathies to Alzheimer's disease. Evidence that any of these interactions are of physiolgical relevance is, however, still lacking.

\section{Prnp - the gene encoding PrP}

The gene encoding the cellular isoform of the prion protein is located on chromosome 20 in humans and on chromosome 2 in mice. It has been cloned by Charles Weissmann and termed Prnp in mouse and PRNP in humans. ${ }^{4}$ In all known mammalian and avian Prnp genes, $\operatorname{PrP}^{\mathrm{C}}$ is encoded by a single open reading frame. The Prnp genes, of mice, sheep and cattle contain three exons, while those of hamsters and humans span over two exons. ${ }^{49}$ PrP expression seems to be controlled by the SP1 transcription factor that binds to $\mathrm{G}+\mathrm{C}$ rich nonamer-regions upstream of exon $1 .{ }^{50}$ Within the genome, Prnp is present as a single copy gene and does not show any homologies to other known cellular genes. Prnp mRNA is constitutively expressed in the adult organism and developmentally regulated during mouse embryogenesis. ${ }^{40}$ Mutations in the host-encoded PrP gene were shown to be genetically linked to human prion diseases. In addition, the PrP gene controls many features of prion diseases such as incubation time, species barrier, and strain specificity. 
Disruption of the Prnp gene demonstrated that an organism that lacks $\operatorname{PrP}^{\mathrm{C}}$ is resistant to infection with prions. ${ }^{7}$

\section{Prnp and Prnd: double trouble?}

Different knockout strategies for disrupting Prnp have been employed. For instance, the so-called Zurich I Prnp ${ }^{0 / 0}$ mice as well as the Edinburgh Prnp ${ }^{-1-}$ used similar approaches thus deleting two thirds of the open reading frame (ORF; 6 Manson, 1994 \#470]. These mice were clinically healthy, although displaying discrete neurophysiological changes and demyelination of peripheral nerves on aging. However, mice of a third PrP knockout line, Nagasaki Prnp ${ }^{-1-}$ developed ataxia and loss of cerebellar Purkinje cells. ${ }^{51,52}$ Since introducing a PrP-encoding cosmid prevented the disease, this phenotype was attributed to PrP. ${ }^{53}$ In contrast to the Zurich I and Edinburgh PrP knockout mice, in the Nagasaki line, not only the ORF, but also parts of intron 2 and the non-coding flanking regions were disrupted. Recent work possibly providing an explanation for the Nagasaki-mice-related phenotype: sequencing of a Prnp-containing cosmid revealed an ORF encoding a protein, christened Doppel (Dpl), $16 \mathrm{~kb}$ downstream of Prnp. ${ }^{54}$ Doppel - encoded by a gene termed Prnd - displays $\sim 25 \%$ identity with the carboxy proximal two thirds of PrP, but lacks a sequence homologous to the amino proximal copper-binding octa repeat region and in particular the highly conserved region 106-126 of $\mathrm{PrP}$, which is essential for its capacity to sustain prion replication. Interestingly, Dpl mRNA is expressed at very low levels in brain of wild-type mice, but - and this could explain the phenotype described above - there are high expression levels in the brain of Nagasaki mice.

Interestingly, $P r n p^{0 / 0}$ mice with an amino proximally truncated transgene encoding PrP devoid of the octa repeats and the conserved 106-125 region suffer from ataxia and degeneration of the cerebellar granule cells shortly after birth. ${ }^{55}$ Introduction of a single intact PrP allele rescues this phenotype. Based on these findings it is thought that PrP interacts with a ligand to obtain an essential signal. In the absence of PrP a notional Prp-like molecule with lower binding affinity possibly substitutes for PrP function. According to this hypothesis, in PrP knockout mice, by interacting with the ligand the truncated PrP could displace the PrP-like molecule, though not eliciting the survival signal. If PrP has the highest affinity for the ligand, it would replace its truncated equivalent and restore function. Because Dpl resembles the truncated PrP, it might cause disease by the same mechanism ${ }^{56,57}$ (Figure 6b).

\section{Mechanism of cell death}

One of the issues that is poorly understood is how and why prions may actually lead to neurodegeneration. The cellular prion protein has been shown to specifically interact with the proto-oncogene product $\mathrm{Bcl}-2$ in the yeast two-hybrid system. ${ }^{58,59} \mathrm{Bcl}-2$ is known to suppress cell death in various cell types. ${ }^{60}$ Interestingly, in contrast to cells derived from a hippocampal cell line expressing $\mathrm{PrP}^{+/+}$the removal of serum from $\mathrm{PrP}^{-1-}$ neurons causes apoptosis that is suppressed by transducing $\mathrm{PrP}^{-1-}$ cells with either PrP or Bcl-2. ${ }^{61}$ Although there is no evidence for direct binding of $\mathrm{PrP}^{\mathrm{C}}$ and $\mathrm{Bcl}-2$ in vertebrate cells, these experiments suggest a functional interaction between $\mathrm{PrP}^{\mathrm{C}}$ and $\mathrm{Bcl}-2$ supporting the idea that a loss of $\mathrm{PrP}^{\mathrm{C}}$ function might trigger apoptotic cell death in prion diseases (Figure 6b).

\section{The species barrier in prion diseases}

Transmission of prions from one species to another is usually accompanied by a prolongation of the incubation period in the first passage and incomplete penetrance of the disease. Subsequent passage in the same species occurs with high frequency and shortened incubation times. ${ }^{62}$ In the case of prion transmission from hamster to mice, this so-called species barrier was overcome by introducing hamster Prnp transgenes into recipient wild-type mice. ${ }^{63}$ Crucially, the properties of the prions produced were compatible with the prion species used for inoculation: infection with hamster prions led to production of hamster prions, whereas infection with mouse prions gave rise to mouse prions. With respect to the protein-only hypothesis these findings can be interpreted as follows: hamster $\mathrm{PrP}^{\mathrm{C}}$ but not murine $\operatorname{PrP}^{\mathrm{C}}$ (the latter differing from the former by 10 amino acids) is an appropriate substrate for conversion to hamster $\operatorname{PrP}^{\mathrm{C}}$ by hamster prions and vice versa. ${ }^{64}$ Intriguingly, susceptibility of mice to prions from other species is increased when the corresponding PrP transgene is introduced into a PrP knockout mouse, suggesting that the resident murine gene inhibits the propagation of the alien prions. ${ }^{7}$

\section{Perplexing prion stains}

Distinct isolates or strains of prions were first described in scrapie-diseased goats, where two dissimilar clinical manifestations ('scratching' and 'drowsy') were identified. ${ }^{65}$ These strains differ in their incubation times in various inbred mouse lines and by their lesion pattern in the brain. Strikingly, distinct strains of prions can be propagated in an inbred mouse strain that is homozygous with respect to $\operatorname{Prnp}^{66}$ - a perplexing finding with regard to the protein-only hypothesis meaning that an identical polypeptide chain is able to mediate different strain phenotypes. Both the 'refolding' and the 'seeding' model propose that each strain is associated with a distinct conformation of $\mathrm{PrP}^{\mathrm{Sc}}$ and that each of these can convert $\mathrm{PrP}^{\mathrm{C}}$ of its host into a likeness of itself. Indeed, $\mathrm{PrP}^{\mathrm{Sc}}$ species associated with two hamster-adapted scrapie strains, namely hyper (HY) and drowsy (DY), proved to display characteristic clinical and histopathological properties as well as distinct biochemical patterns with respect to proteinase $\mathrm{K}$ digestion ${ }^{67}$ - readily explainable by the presence of different conformations of $\mathrm{PrP}^{\mathrm{Sc}}$. Analogous findings have been made with other prion strains propagated in mice. ${ }^{10,68}$ In addition, $\mathrm{PrP}^{\mathrm{Sc}}$ of certain strains differs in the ratio of diglycosylated to monoglycosylated form. ${ }^{13}$ Based on the fragment size and the relative abundance of individual bands, three distinct patterns (PrP ${ }^{S c}$ types $\left.1-3\right)$ were defined for sporadic and iatrogenic CJD cases. In contrast, all cases of nvCJD displayed a novel pattern, designated as type-4 pattern (Figure 3). Interestingly, brain-extracts from BSE-infected cattle as well as BSE-inoculated macaques exhibited a type-4 


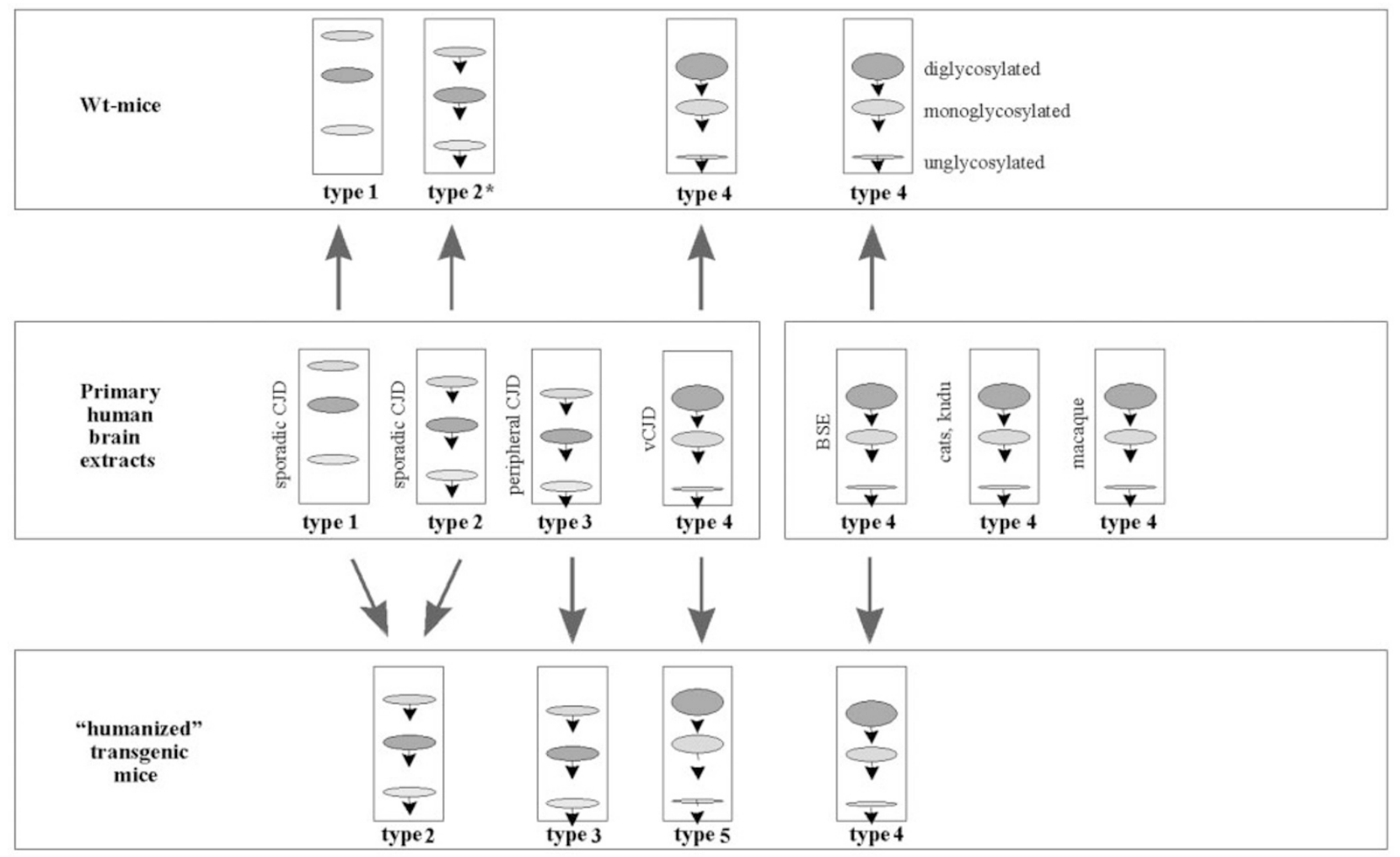

Figure 3 Patterns of PrP glycosylation. Representation of the three glycosylated PrPSc moieties (non-, mono-, and diglycosylated PrPSc) in immunoblots of brain extracts after digest with proteinase K. Different inocula result in specific mobilities of the three PrP bands as well as different predominance of certain bands (middle panel). These characteristic patterns can be retained, or changed to other predictable patterns after passage in wild-type (upper panel) or humanized mice (PrP-deficient mice bearing a human PrP transgene, lower panel). Based on the fragment size and the relative abundance of individual bands, three distinct patterns (PrP ${ }^{S c}$ types 1-3) were defined for sporadic and iatrogenic CJD cases. In contrast, all cases of nvCJD displayed a novel pattern designated as type-4 pattern

pattern. Even more intriguingly, transmission of BSE or nvCJD to mice produced mouse $\mathrm{PrP}^{\mathrm{Sc}}$ with a type-4 pattern indistinguishable from the original inoculum ${ }^{10}$ - findings that impressively support the hypothesis that nvCJD is the human counterpart to BSE. A more powerful tool (eventually serving as diagnostic tool to characterize prion strains) has been provided by the group of Prusiner utilizing the differential affinity of anti-PrP ${ }^{\mathrm{Sc}}$-antibodies, thus differentiating as many as eight different strains. ${ }^{69}$ Also, this provides further evidence for the assumption that strain specificity is encrypted within the physical structure of PrP.

Studies of scrapie in inbred mice led to identification of a single autosomal gene, termed Sinc (scrapie incubation), controlling incubation time of mice infected with mouse prion strains. $^{70,71}$ Soon after, a link between Sinc and a polymorphism in the mouse Prnp gene was discovered and it has been demonstrated that Sinc is identical with to Prnp by exchanging Prnp alleles of inbred mice. ${ }^{72}$

\section{Clinical and histopathological characteristics of prion diseases}

Sheep scrapie is the prototype of the growing group of TSEs. The typical symptoms of scrapie-sick sheep include hyper- excitability, pruritus and myoclonus. The disease is characterized by a rapid progression leading to tetraparesis and ultimately to the death of the affected animal.

The clinical symptoms of BSE are insidious, and consist of behavioural changes (including aggressive behaviour, which is proverbially atypical in cows), and uncoordinated gait. Histologically, the brain exhibits lesions similar to those of TSEs in other species. ${ }^{73}$ It has not been excluded that cases of BSE may have been seen in England as early as 1985 , but probably not before that year despite earlier anecdotal reports. The number of cases continued to increase, resulting in a major epidemic, and peaking in the summer of 1992 . $^{21}$

It was suggested early on that one common exposure of cattle to prions came about through the use of a dietary protein supplement, meat and bone meal (MBM), that was regularly fed to them after weaning. No credible alternative hypothesis has been put forward regarding the origin of the BSE epidemic, and the incidence of new cases has been precipitously declining some 4-5 years after a more-orless effective ban of MBM was put into place.

Since the first description of CJD by Jakob and Creutzfeldt, ${ }^{74}$ five human diseases have been identified as TSEs (Table 1). ${ }^{11,12,75} \mathrm{~A}$ striking hallmark applying to all 
TSEs is that the brain is heavily affected in sharp contrast to the body that remains unharmed. To ultimately diagnose human prion diseases, a histopathological assessment of the central nervous system is essential. The communal lesions are neuronal loss, spongiosis and astrogliosis, accompanied by an accumulation of microglia and, occasionally, the presence of amyloid plaques and various kinds of small deposits immunolabeled with anti-PrP antibodies (Figure 4). ${ }^{11,76,77}$ These deposits are variable in their number and topography, hence representing one of a number of phenotypic variations typical of the various forms of human prion disease. Thus, future classifications of these disorders are likely to incorporate genetic and biochemical data in addition to clinical and pathological parameters. CJD occurs sporadically with an incidence of approximately one case per million per year, may be transmitted and has a genetic basis in roughly $10 \%$ of all cases. Clinically, patients suffering from CJD show a wide spectrum of diversely associated symptoms. Besides the typical rapidly progressive form including dementia, myoclonus, cerebellar ataxia, visual disturbances and periodic sharp waves seen with electroencephalography (EEG), other forms of the disease exist and may give rise to diagnostic difficulties. Albeit not diagnostic, periodic EEG or 14-3-3 protein detection in spinal fluid are helpful in

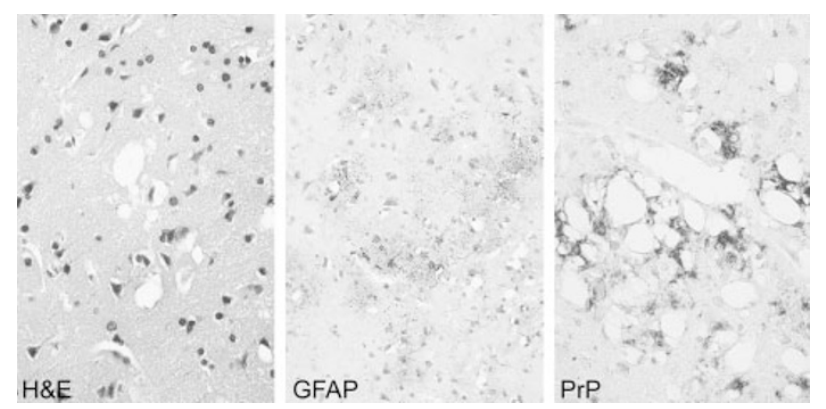

Figure 4 Characteristic neuropathologic features of transmissible spongiform encephalopathies. Grey matter of the brain of a CJD patient stained with Hematoxylin-Eosin (HE) displaying the characteristic spongiform, vacuole-like morphology (left). Activation and proliferation of reactive, swollen astrocytes is visualized by staining with antibodies against glial fibrillary acidic protein (GFAP, middle). Immunohistochemical staining using anti-PrP antibodies representing prion protein deposits (right) making the diagnosis, when clinical symptoms are present. Interestingly, there are no general symptoms such as fever or leukocytosis reminiscent of a humoral immune response. ${ }^{75,78}$

The most recently recognized form of CJD in humans, new variant CJD (nvCJD), was first described in 1996 and has been linked to BSE. ${ }^{79}$ It represents a distinct clinicopathological entity that is characterized at onset by psychiatric abnormalities, sensory symptoms and ataxia, eventually leading to dementia along with other features usually observed in sporadic CJD. What distinguishes nvCJD from sporadic cases is that the age of patients is abnormally low (nvCJD: 19-39 years; sporadic CJD: 5570 years) and the duration of the illness is rather long (nvCJD: 7.5-22 months; sporadic CJD: 2.5-6.5 months). Moreover, new variant CJD displays a distinct pathology within the brain characterized by abundant 'florid plaques', decorated by a daisy-like pattern of vacuolation. Most cases of nvCJD have been observed in the UK.

Other genetic diseases in humans are GerstmannSträussler-Scheinker (GSS) syndrome and fatal familial insomnia (FFI). GSS is transmitted by autosomal dominant inheritance. ${ }^{80,81}$ It is characterized by missense mutations of the gene encoding PrP (PRNP, Figure 5), ${ }^{82}$ associated with specific neuropathological lesions, and by multicentric amyloid plaques that can be visualized by antibodies directed against the prion protein. This restrictive definition justifies retaining the name of Gerstmann-SträusslerScheinker syndrome and excludes observations of hereditary prion diseases without multicentric amyloid plaques, as well as sporadic forms with multicentric plaques. It has been possible to transmit GSS to chimpanzees and to mice. An additional member of the group of TSEs, FFI, was also transmitted experimentally, in at least three instances to mice. ${ }^{83}$ Kuru is a form of spongiform encephalopathy transmitted by ritual cannibalism, which affected the Fore population in the Northern provinces of New Guinea. ${ }^{84}$

\section{Acquired forms of prion diseases in humans (Table 2)}

Direct transmissions of brain-derived material from a patient suffering from Creutzfeldt-Jakob disease to other persons

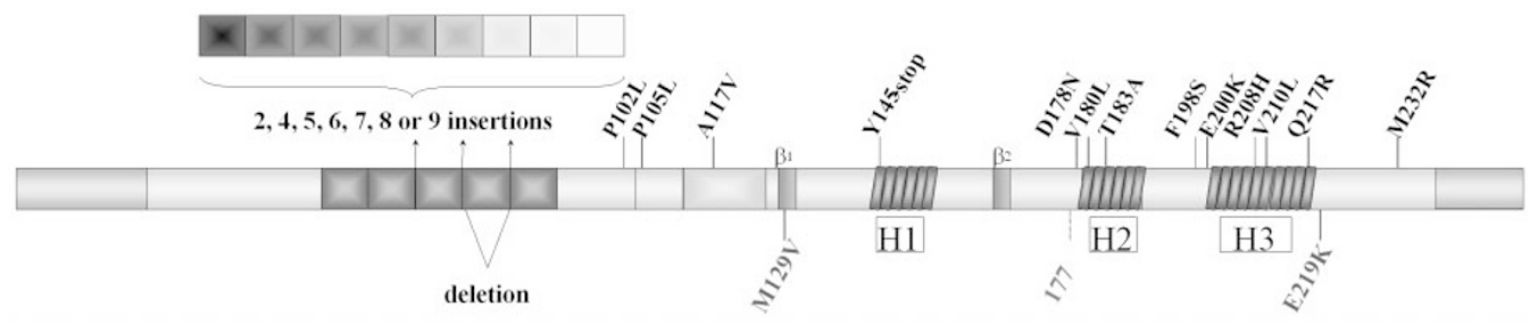

Figure 5 Schematic drawing of the coding region of the human PRNP gene. Mutations that segregate with inherited prion diseases are shown above, as well as non-pathogenic polymorphisms (M129V, E219K) and silent mutations (177). The $\mathrm{N}$ - and C-terminal domains are signal peptides that are cleaved off during maturation of $\operatorname{PrP}^{C}$ (see also Figure 2). Octa repeat regions are represented by grey boxes, and pathogenic octa repeat insertions of $16,32,40,48,56,64$ and 72 amino acids are shown above. Deletion of one octa repeat stretch does not appear to segregate with a neurodegenerative disorder. There is an apparent clustering of pathogenic mutations associated with a CJD phenotype around the $\alpha$-helical domains (H1, H2, H3) while amino acid exchanges associated with a GSS phenotype are located further upstream around the conserved region 
Table 2 Acquired human prion diseases

\begin{tabular}{ll}
\hline Disease & Mechanism of pathogenesis \\
\hline latrogenic CJD & prion-contaminated electrodes \\
& human pituitary growth hormone \\
& human pituitary gonadotropin \\
dura mater grafts & cornea grafts \\
infection from BSE prions \\
(hypothesized)
\end{tabular}

were proven to result in transmission of disease, when electrodes used for cortical recordings from Creutzfeldt-Jakob patients were sterilized using formaldehyde vapors and alcohol, and used in additional patients. Moreover, several thousands of patients, predominantly in Japan, may have been exposed to the CJD agent via preparations of prioncontaminated dura mater, although less than $2 \%$ of those exposed have developed disease so far. ${ }^{85,86}$ Also, corneal transplantation has most likely resulted in transmission of the disease in the USA two decades ago. The largest problem with iatrogenic transmission of CJD occurred as result of peripheral administration of pituitary hormones of cadaveric origin. ${ }^{86,87}$ Nonetheless, iatrogenic transmission is a rare event. This can be explained in two ways: either by the long incubation time of prion diseases - especially in the above described case of extracerebrally administered growth hormone - assuming that further cases may arise in the future; or by some host factors, in addition to the virulence of prions, which may affect the probability that infection takes place, thus either protecting or sensitizing individuals exposed to CJD prions.

The observations that latency after intracerebral contamination (such as cornea and dura mater transplants) is much shorter than latency after peripheral infection (as in the case of extracerebral application of pituitary hormones) is in agreement with experimental data from animal models, and suggest that a rather prolonged period of extracerebral events possibly including replication of the agent and invasion of specific extraneuronal systems may be a precondition to prion neuroinvasion.

\section{Prion diseases without PrPsc}

An abnormal $\operatorname{PrP}\left(\mathrm{PrP}^{\mathrm{Sc}}\right)$ is a characteristic feature of most prion diseases. However, in some inherited cases the predominant form of $\mathrm{PrP}$ detectable in the brain is not $\mathrm{PrP}$ but rather ${ }^{\mathrm{CTM}} \operatorname{PrP}$, a transmembrane form of the prion protein. ${ }^{88}$ This finding applies to a subset of patients with Gerstmann-Sträussler-Scheinker syndrome, who carry a distinct mutation in the Prnp gene, i.e. a substitution of alanine $(A)$ for valine $(\mathrm{V})$ at position 117 (A117V, Figure 5). Interestingly, this mutation, which leads to the irreversible neurodegeneration characteristic of prion diseases, neither produces conventional $\mathrm{PrP}^{\mathrm{Sc}}$, nor transmits it to laboratory rodents. Recently, it was shown that the effectiveness of accumulated $\mathrm{PrP}^{\mathrm{Sc}}$ in causing neurodegenerative disease may indeed depend upon the predilection of host-encoded PrP to be made into the ${ }^{\mathrm{CTM}} \operatorname{PrP}$ form. ${ }^{89}$ In addition, the time course of $\mathrm{PrP} \mathrm{P}^{\mathrm{Sc}}$ accumulation seems to modulate the events involved in the generation of ${ }^{C}{ }^{\mathrm{M}} \mathrm{PrP}$, suggesting a common mechanism in the pathogenesis of both genetic and acquired prion diseases $^{57}$ (Figure 6b). If true, this hypothesis may also explain why in many instances of human and experimental TSE extremely little $\mathrm{PrP}^{\mathrm{Sc}}$ can be detected, even in terminal disease.

\section{Neuroinvasion - how prions pave their way to the brain}

Acquired forms of prion diseases are by and large transmitted through oral uptake of the agent or peripheral administration (Table 2) - such as intramuscular injection of growth hormone and, to a lesser extent, pituitary gonadotropins - raising the question of how prions find their way to the CNS.

Neuroectodermal tissue of $\mathrm{Prnp}^{+/+}$mice postnatally grafted into the brain of $\mathrm{Prnp}^{\mathrm{O} / \mathrm{O}}$ mice develops into differentiated Prnp ${ }^{+/+}$nervous tissue. Intracerebral inoculation of such engrafted mice leads to typical scrapie pathology within the graft but not in the surrounding $\mathrm{Prnp}^{0 / 0}$ tissue, while intraperitoneal infection does not, suggesting that prion transport from periphery to CNS requires interposed $\mathrm{PrP}$-bearing tissue. ${ }^{90,91}$ Since no pathology can be identified in organs other than the CNS it is of great importance to identify 'reservoirs' within the periphery in which prions (silently) multiply during the incubation phase of the disease.

One such reservoir of $\mathrm{PrP}^{\mathrm{Sc}}$ or infectivity is doubtlessly the immune system, and a wealth of early studies points to the importance of prion replication in lymphoid organs. $^{92,93}$ The nature of the cells supporting prion replication within the lymphoreticular system, however, is still uncertain. Inoculation of various genetically modified immunodeficient mice lacking different components of the immune system with scrapie prions revealed that the lack of B-cells renders mice unsusceptible to experimental scrapie. ${ }^{94}$ While defects affecting only T-lymphocytes had no apparent effect, all mutations affecting differentiation and responses of B-lymphocytes prevented development of clinical scrapie. Since absence of B-cells and of antibodies correlates with severe defects in follicular dendritic cells (FDCs), the lack of any of these three components may prevent clinical scrapie. Yet mice expressing immunoglobulins exclusively of the $\lg M$ subclass without detectable specificity for $\operatorname{PrP}^{\mathrm{C}}$, developed scrapie after peripheral inoculation: Thus, differentiated B-cells seem crucial for neuroinvasion of scrapie regardless of B-cell receptor specificity. FDCs have been incriminated, because $\mathrm{PrP}^{\mathrm{Sc}}$ accumulates in FDCs of wildtype and nude mice (which suffer from a selective T-cell defect). ${ }^{95}$ Additional intriguing arguments for a crucial role of FDCs are presented by recent findings demonstrating that switching off FDCs (by treating mice with soluble lymphotoxin- $\beta$ receptor) abolishes splenic prion accumulation and retards neuroinvasion, thus indicating a central function for FDCs in either accumulating or even propagating prions. ${ }^{96}$

Repopulation of immunodeficient mice with fetal liver cells (FLCs) from either PrP-expressing or PrP-deficient mice and 
from T-cell deficient mice, but not from B-cell deficient mice, is equally efficient in restoring neuroinvasion after intraperitoneal inoculation of scrapie prions. ${ }^{94}$ This suggests that cells whose maturation depends on B-cells or their products (such as FDCs) may enhance neuroinvasion. Alternatively, B-cells may transport prions to the nervous system by a PrPindependent mechanism, since PrP expression in B cells is not required for prion neuroinvasion. ${ }^{97}$

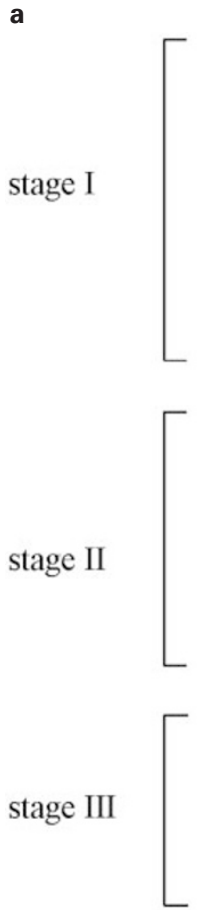

b

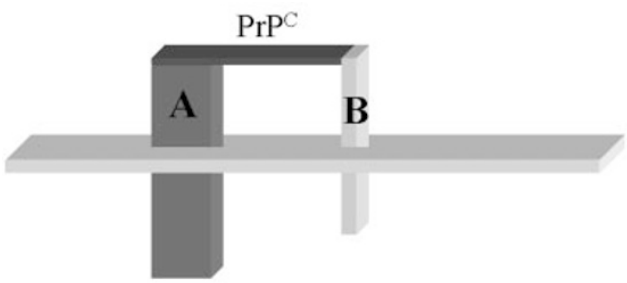

$\operatorname{PrP}^{\mathrm{C}}$ mediating juxtaposition between transmembrane molecules A and B

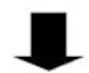

signal for cell survival

nascent $\mathrm{PrP}$

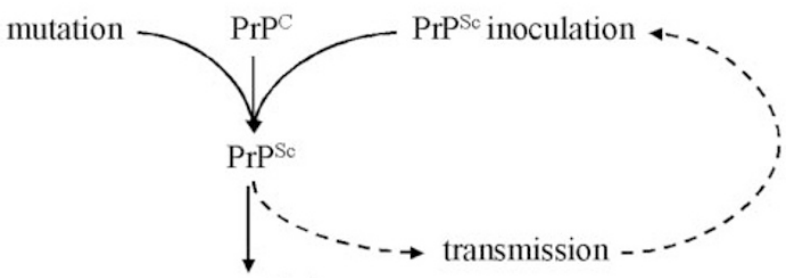

accumulation

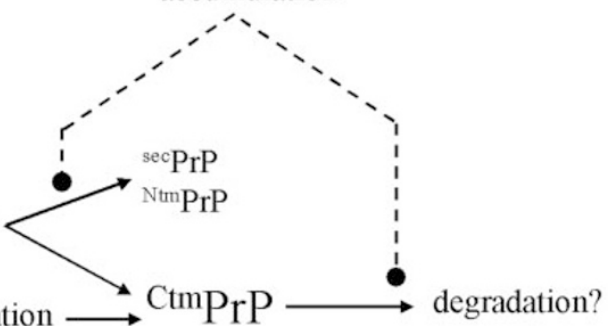

exit to post-endoplasmatic-reticulum compartment

neurodegeneration

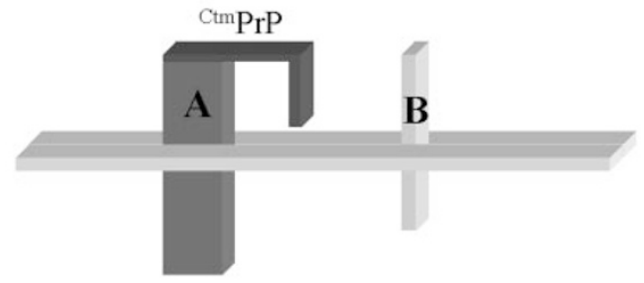

CmPrP disrupting juxtaposition between transmembrane molecules A and B

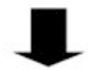

signal for cell survival missing

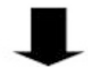

cell death

Figure 6 (a) Three stage model of prion pathogenesis (adapted from ${ }^{89}$ ). Stage I represents the formation and accumulation of PrP $\mathrm{P}^{\mathrm{Sc}}$, initiated by either inoculation or spontaneous conversion of a mutated $\mathrm{PrP}^{\mathrm{C}}$ to $\mathrm{PrP}^{\mathrm{Sc}}$. Stage II symbolizes the events involved in generating ${ }^{\mathrm{Ctm}} \mathrm{PrP}$, either by an unknown process involving $\mathrm{PrP}^{\mathrm{Sc}}$ (characterized by dashed lines) or by certain mutations within PrP. Two distinct forms of PrP can be made at the endoplasmatic reticulum: one that is fully translocated ( $\left.{ }^{\mathrm{sec}} \mathrm{PrP}\right)$ and one that is transmembrane. Digestion with proteases of the latter one results in two fragments: one is $\mathrm{COOH}$-terminal derived and glycosylated, the other is $\mathrm{NH}_{2}$-terminal derived and unglycosylated; thus, the first one is termed C-transmembrane PrP ( ${ }^{\mathrm{Ctm} P r P}$ ) with the $\mathrm{COOH}$-terminus in the $\mathrm{ER}$ lumen and the $\mathrm{NH}_{2}$-terminus accessible to proteases in the cytosol, whereas the second one is termed $\mathrm{N}$-transmembrane PrP (NtmprP) with an opposite conformation. Stage III hypothesizes on the events involved in ${ }^{\mathrm{Ctm}} \mathrm{PrP}$-mediated neurodegeneration, possibly involving the exit of ${ }^{\mathrm{Ctm}} \mathrm{PrP}$ to a post-endoplasmaticreticulum compartment as a first step that is schematically explained in (b). (b) Possible role of ${ }^{\mathrm{Ctm} P r P}$ in cell death (adapted from ${ }^{57}$ ). The full-length PrP possibly acts as a co-receptor on the cell surface, mediating the juxtaposition of two cell-surface transmembrane molecules $A$ and $B$. This generates a signal for cell survival in the cytosol. Failure of ${ }^{\mathrm{Ctm}} \mathrm{PrP}$ to bind $\mathrm{B}$ could induce cell death by not facilitating the association of $\mathrm{A}$ to $\mathrm{B}$. This mechanism could also explain effects of expression of an amino-terminally truncated $\operatorname{PrP}\left(\right.$ ref. $\left.^{55}\right)$ as well as the Doppel gene product ${ }^{54}$ 
However, immune cells are unlikely to transport the agent all the way from the lymphoreticular system to the CNS, since prion replication occurs first in the CNS segments to which the sites of peripheral inoculation project. This implies that the agent finally may spread through other compartments, such as the peripheral nervous system (Figure 7). ${ }^{98,99}$

\section{Brain-specific aspects of prion pathogenesis}

One of the crucial questions remaining to be answered is why only the brain is affected in prion diseases. Accumulation of $\mathrm{PrP}^{\mathrm{Sc}}$ is not a brain-specific finding, since one can detect $\mathrm{PrP}^{\mathrm{Sc}}$ deposits in peripheral organs such as the spleen. While the prime target of damage within the brain seems to be neuronal, profound neuronal loss is not always seen in TSEs. Instead, activation of astrocytes occurs very early and in an extremely consistent fashion (Figure 4). ${ }^{100}$ It can be easily reproduced in vitro, and leads to significant physiological effects such as impairment of the blood-brain-barrier. ${ }^{101,102}$ Additionally, astrocytes belong to the few cell-types identified that are capable of supporting prion replication. ${ }^{103}$

Growing evidence incriminates another cell type in brain damage, not only in TSEs but in diseases ranging from Alzheimer's to multiple sclerosis and even stroke: microglial cells, the brain's intrinsic macrophages. ${ }^{104}$ In vitro experiments seem to indicate that activation of microglia may be quite pivotal in effecting neuronal damage in TSEs, and that this phenomenon is dependent on expression of $\mathrm{PrP}^{\mathrm{C}} \cdot{ }^{105}$ Moreover, microglial activation and accumulation in affected brain areas precede neuronal cell death and parallel the temporal and spatial pattern of $\mathrm{PrP}^{\mathrm{Sc}}$ deposition. ${ }^{77}$ The details of this pathway of neuronal cell death, however, still escape our understanding, and the proof that these phenomena occur in the brain during the course of the disease is still missing.

\section{Therapeutic approaches}

Because of the unusual properties of TSEs, standard antiviral and antibacterial approaches to these diseases are obviously useless. The situation is further complicated by the fact that there is almost no immune response to infection. Over the past 25 years a variety of different classes of compounds have been tested as inhibitors of TSEs that include antiviral, antibacterial and antifungal drugs, hormones, immunosuppressants and sulfated polyanions. However, none of these substances have been particularly successful: when prion diseases become clinically apparent, damage to the brain is typically extensive, and it is not surprising that pharmacological treatment is ineffective.

Since most cases of TSEs are induced by peripheral infection, and prion titers rise in lymph nodes and spleen before transfer to the CNS, post-exposure prophylaxis, which aims at preventing neuroinvasion, may be feasible. Promising studies involve the use of pentosan polysulphate (PS), a polyanionic sulphated polysaccharide closely related to cell-derived glycosaminoglycans, that recently has been shown to prolong scrapie incubation time and to reduce disease susceptibility in mice. ${ }^{106}$ However, PS only showed its protective effect when given both intraperitoneally and at a timepoint close to the i.p. prion infection. Oral administra-
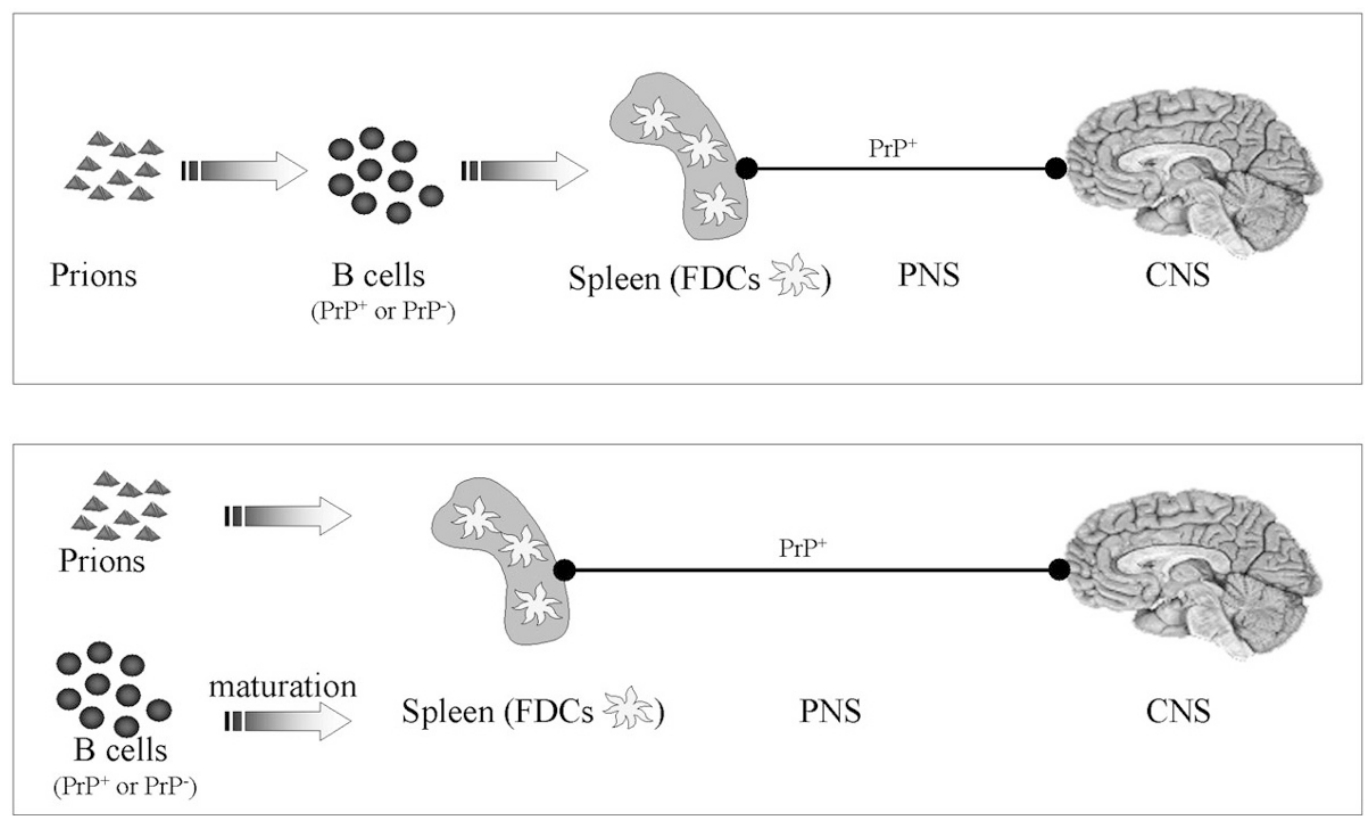

Figure 7 Possible models for prion neuroinvasion. In the upper panel, B lymphocytes, which may be genotypically PrP-positive or PrP-negative, carry physically prions to their sites of replication in spleen. These may be represented, in part or entirely, by follicular dendiritic cells (FDSs). Neuroinvasion proper then occurs preferentially along fibers of the peripheral nervous system (PNS), which may support transfer of prions to the central nervous system (CNS) depending on their own expression of $\mathrm{PrP}^{\mathrm{C}}$. The lower panel illustrates a second possibility, i.e. that B cells are not directly involved in neuroinvasion. In this instance, the crucial role of B-cells in neuroinvasive scrapie relies on their function in inducing maturation of FDCs 
tion of PS was ineffective, perhaps because of its poor bioavailability upon delivery via the gastrointestinal tract. Since the blood-brain-barrier is practically non-permeable to PS, putative targets of PS must be situated within the periphery. Other potential anti-TSE drugs are certain cyclic tetrapyrroles, i.e. porphyrins and phtalocyanines that have been demonstrated to inhibit the formation of $\mathrm{PrP}^{\mathrm{Sc}}$ in vitro. ${ }^{107}$ In vivo, these compounds have recently also been shown to delay onset of scrapie in mice when administered over 4 weeks starting at the time of i.p. prion infection.

Of all substances tested, phtalocyanine tetrasulfonate (PcTS), a cyclic tetrapyrrole, displayed the strongest effects in inhibiting $\mathrm{PrP}^{\mathrm{Sc}}$ formation in vitro, and resulted in the most successful delay of disease onset in mice. ${ }^{108}$ Again, there was no prolonged incubation time when the drug was given weeks after the prion infection. Another promising approach to delaying scrapie in mice is based on interfering with the conformational transition of $\mathrm{PrP}^{\mathrm{C}}$ into $\mathrm{PrP}^{\mathrm{Sc}}$. Soto and colleagues could demonstrate that a 13-residue $\beta$ sheet breaker peptide (iPrP13) partly reversed in vitro $\mathrm{PrP}^{\mathrm{Sc}}$ to a biochemical and structural state similar to that of $\mathrm{PrP}^{\mathrm{C}} 109$

Treatment of infectious prions with iPRP13 prior to infection delayed onset of clinical symptoms and decreased infectivity by about $90 \%$ in mice with experimental scrapie thus possibly representing a novel therapeutic approach to prion diseases. Thus, all putative anti-TSE drugs tested to date are of prophylactic rather than therapeutic usage. Certainly, there is an urgent need for strategies to deal with infected individuals, because millions of people may have been exposed to BSE in the 1980s and possibly in the early 90 s.

\section{Yeast prions}

For more than 20 years the genetic analysis of two unrelated mutants of the yeast Saccharomyces cerevisiae resulted in a substantial dilemma for yeast researchers. The two mutants in question, the $\left[\mathrm{PSI}^{+}\right]$mutant (modifying the efficiency of nonsense suppression) and the [URE3] mutant (causing an alteration in nitrogen metabolism) failed to behave according to Mendel's laws. Thus, it was suggested that the unusual genetic properties of both mutants could be explained by a prion-like behavior of the two previously identified yeast proteins: $\left[P S I^{+}\right]$is associated with Sup35p (also known as eRF3), an essential component of the translation termination machinery, whereas [URE3] is associated with Ure2p, a protein that negatively regulates nitrogen metabolism. ${ }^{110}$ Lately, further yeast proteins with a prion-like behavior have been discovered; amongst them is Rnqlp fulfilling all diagnostic criteria of yeast prions, although not obviously associated with a specific phenotype. ${ }^{111}$

Strikingly, the prion-forming domain (PrD) of Sup35p very recently has been shown to be both modular and transferable. An artificial prion was generated by fusing a recombinant version of a mammalian receptor to the Sup35p-PrD.$^{112}$ The fusion protein altered the biochemical properties of yeast cells in ways that could be inherited by progeny cells. Not only strongly supporting the 'protein only' hypothesis, the modular and transferable properties of yeast $\operatorname{PrD}$ have both fundamental evolutionary and great biotechnological implications if broadly applicable. In a further set of experiments, it was shown that both yeast and a neural tumour cell line cytoplasmatically expressing mouse PrP acquired the characteristics of $\mathrm{PrP}^{\mathrm{Sc}}$; that is detergent insolubility and resistance to protease digestion. ${ }^{113}$ Studies of infectivity of these transgenetically synthesized prions have not yet been performed, but, in case of a positive outcome, would come close to verifying the protein-only hypothesis. However, unlike the yeast prion-forming domains Sup35p and Ure2p, mammalian PrP is not a cytoplasmic protein. Formation of $\mathrm{PrP}^{\mathrm{Sc}}$ occurs after it traverses the plasma membrane into a subcellular compartment. Formation of $\mathrm{PrP}^{\mathrm{Sc}}$ thus occurs in a very different molecular and ionic environment to that in which yeast prions form raising the question of whether a coplayer may be involved, namely the so-called protein $X$. Although the cytoplasmic molecular chaperone Hsp104 is known to be essential for the formation and maintenance of the prion form of Sup35p in yeast, neither Hsp104 nor an analogous chaperone or enzyme - in other words the puzzling protein $X$ - has been proven to be involved in $\mathrm{PrP}^{\mathrm{Sc}}$ formation. However, whether transgenic mouse $\mathrm{PrP}^{\mathrm{Sc}}$ expression in yeast is Hsp104-dependent has not been reported.

Overall, yeast is providing a very powerful and experimentally testable paradigm for prions, although caution must be taken in directly extrapolating findings with yeast prions to the mammalian system.

\section{Outlook}

Given the wealth of research data on transmissible spongiform encephalopathies, it is tempting to declare that prion diseases constitute the best-understood form of neurodegeneration. Yet it would be deceptive to neglect the fact that most of the mechanisms governing prion replication are not understood: not only the details, but even the very core of the problem is still obscure.

Certainly, understanding of prion pathogenesis has progressed rapidly - but this is a topic that can be often dealt with even in the absence of ultimate certainty about the nature of the infectious agent. However, it is sobering to realize that the prion hypothesis proper is still awaiting irrefutable confirmation. Although each individual piece of evidence (human genetics, transgenic mice, in vitro conversion experiments, etc.) strongly supports the proposition that the prion is composed partly or entirely of a PrP-derived molecule and informational nucleic acids are not required for its infectious properties, the available data still does not provide incontrovertible proof of the hypothesis. Equally frustrating are attempts at establishing sensitive diagnostic procedures: the best assays described still do not reach the sensitivity of PCR reactions used for routine detection of viruses. Finally, even if intriguing prionostatic regimens are being developed, we are still very far from an effective and useful proposal for post-exposure prophylaxis or for treatment of prion diseases. 


\section{References}

1. Riesner D, Kellings K, Wiese U, Wulfert M, Mirenda C and Prusines SB (1993) Prions and nucleic acids: search for "residual" nucleic acids and screening for mutations in the PrP-gene. Dev. Biol. Stand. 80: 173-181

2. Chesebro B (1998)BSE and prions: uncertainties about the agent. Science 279: $42-43$

3. Prusiner SB (1982) Novel proteinaceous infectious particles cause scrapie. Science 216: $136-144$

4. Basler K, Oesch B, Scott M, Westaway D, Walchli M, Groth DF,McKinley MP, Prusiner SB and Weissmann C (1986) Scrapie and cellular PrP isoforms are encoded by the same chromosomal gene. Cell 46: 417-428

5. Chesebro B, Race R, Wehrly K, Nishio J, Bloom M, Lechner D, Bergstrom S Robbins K, Mayer L and Keith JM (1985) Identification of scrapie prion proteinspecific mRNA in scrapie-infected and uninfected brain. Nature 315: 331-333

6. Büeler HR, Fischer M, Lang Y, Bluethmann H, Lipp HP, DeArmond SJ, Prusiner SB, Aguet M and Weissmann C (1992) Normal development and behaviour of mice lacking the neuronal cell-surface PrP protein. Nature 356: 577-582

7. Büeler HR, Aguzzi A, Sailer A, Greiner RA, Autenried $P$, Aguet $M$ and Weissmann C (1993) Mice devoid of PrP are resistant to scrapie. Cell 73: 1339 1347

8. Sailer A, Büeler H, Fischer M, Aguzzi A and Weissmann C. (1994) No propagation of prions in mice devoid of PrP. Cell 77: 967-968

9. Bruce ME, Will RG, Ironside JW, McConnell I, Drummond D, Suttie A,McCardle L, Chree A, Hope J, Birkett C, Cousens S, Fraser H and Bostock CJ (1997) Transmissions to mice indicate that 'new variant' CJD is caused by the BSE agent [see comments]. Nature 389: 498-501

10. Hill AF, Desbruslais M, Joiner S, Sidle KC, Gowland I, Collinge J,Doey LJ and Lantos P (1997) The same prion strain causes VCJD and BSE [letter] [see comments]. Nature 389: 448-450

11. Aguzzi A (1996) Between cows and monkeys. Nature 381: 734

12. Aguzzi A, Weissmann C (1996) Spongiform encephalopathies: a suspicious signature. Nature 383: 666-667

13. Collinge J, Sidle KC, Meads J, Ironside J and Hill AF (1996) Molecular analysis of prion strain variation and the aetiology of 'new variant' CJD. Nature 383:685690

14. Prusiner SB (1989) Scrapie prions. Annu. Rev. Microbiol. 43: 345-374

15. Cuille $J$ and Chelle PL (1939) Experimental transmission of trembling to the goat. CR Seances Acad. Sci. 208: 1058-1160

16. Griffith JS (1967) Self-replication and scrapie. Nature 215: 1043-1044

17. Gajdusek DC, Gibbs CJ and Alpers M (1966) Experimental transmission of a Kuru-like syndrome to chimpanzees. Nature 209: 794-796

18. Gibbs Jr CJ, Gajdusek DC, Asher DM, Alpers MP, Beck E, Daniel PM and Matthews WB (1968) Creutzfeldt-Jakob disease (spongiform encephalopathy): transmission to the chimpanzee. Science 161: 388-389

19. Kahana E, Alter M, Braham J and Sofer D (1974) Creutzfeldt-Jakob disease: focus among Libyan Jews in Israel. Science 183: 90-91

20. Hsiao K, Meiner Z, Kahana E, Cass C, Kahana I, Avrahami D, Scarlato G Abramsky O, Prusiner SB and Gabizon R (1991) Mutation of the prion protein in Libyan Jews with Creutzfeldt-Jakob disease. N. Engl. J. Med. 324: 1091 - 1097

21. Weissmann C and Aguzzi A (1997) Bovine spongiform encephalopathy and early onset variant Creutzfeldt-Jakob disease. Curr. Opin. Neurobiol. 7: 695700

22. Telling GC, Haga T, Torchia M, Tremblay P, Dearmond SJ and Prusiner SB (1996) Interactions between wild-type and mutant prion proteins modulate neurodegeneration transgenic mice. Genes Dev. 10: 1736-1750

23. Manson JC, Jamieson E, Baybutt H, Tuzi NL, Barron R, McConnell I,Somerville R, Ironside J, Will R, Sy MS, Melton DW, Hope J and Bostock C (1999) A single amino acid alteration (101L) introduced into murine PrP dramatically alters incubation time of transmissible spongiform encephalopathy. EMBO J. 18 $6855-6864$

24. Riek R, Hornemann S, Wider G, Billeter M, Glockshuber R and Wuthrich K (1996) NMR structure of the mouse prion protein domain $\operatorname{PrP}(121-321)$. Nature 382: $180-182$

25. Riek R, Hornemann S, Wider G, Glockshuber R and Wüthrich K (1997) NMR characterization of the full-length recombinant murine prion protein, $\operatorname{mPrP}(23$ 231). FEBS Lett. 413: 282-288
26. Hornemann S, Korth C, Oesch B, Riek R, Wider G, Wuthrich Kand Glockshuber R (1997) Recombinant full-length murine prion protein, $\operatorname{mPrP}(23-231)$ : purification and spectroscopic characterization. FEBS Lett. 413: 277-281

27. Riek R, Wider G, Billeter M, Hornemann S, Glockshuber R and Wuthrich K. (1998) Prion protein NMR structure and familial human spongiform encephalopathies. Proc. Natl. Acad. Sci. U.S.A. 95: 11667-11672

28. Pan KM, Baldwin M, Nguyen J, Gasset M, Serban A, Groth D, Mehlhorn I, Huang Z, Fletterick RJ, Cohen FE, et al. (1993) Conversion of alpha-helices into betasheets features in the formation of the scrapie prion proteins. Proc. Natl. Acad. Sci. U.S.A. 90: $10962-10966$

29. Telling GC, Scott M, Mastrianni J, Gabizon R, Torchia M, Cohen FE, DeArmonds SJ and Prusiner SB (1995) Prion propagation in mice expressing human and chimeric PrP transgenes implicates the interaction of cellular PrP with another protein. Cell 83: $79-90$

30. Jarrett JT and Lansbury Jr PT (1993) Seeding 'one-dimensional crystallization' of amyloid: a pathogenic mechanism in Alzheimer's disease and scrapie? Cell 73: $1055-1058$

31. Kocisko DA, Priola SA, Raymond GJ, Chesebro B, Lansbury Jr PT and Caughey $B(1995)$ Species specificity in the cell-free conversion of prion protein to protease-resistance forms: a model for the scrapie species barrier. Proc. Natl. Acad. Sci. U.S.A. 92: 3923-3927

32. Kocisko DA, Lansbury PT and Caughey B (1996) Partial unfolding and refolding of scrapie-associated prion protein - evidence for a critical $16-\mathrm{kDa}$ C-terminal domain. Biochemistry 35: $13434-13442$

33. Bessen RA, Kocisko DA, Raymond GJ, Nandan S, Lansbury PT and Caughey B (1995) Non-genetic propagation of strain-specific properties of scrapie prion protein. Nature 375: 698-700

34. Bessen RA, Raymond GJ and Caughey B (1997) In situ formation of proteaseresistant prion protein in transmissible spongiform encephalopathy-infected brain slices. J. Biol. Chem. 272: 15227-15231

35. DeArmond SJ, Sanchez H, Yehiely F, Qiu Y, Ninchak-Casey A, Daggett V, Camerino AP, Cayetano J, Rogers M, Groth D, Torchia M, Tremblay P, Scott MR, Cohen FE and Prusiner SB (1997) Selective neuronal targeting in prion disease Neuron 19: 1337-1348

36. DeArmond SJ, Qu Y, Sanchez H, Spilman PR, Ninchak-Casey A, Alonso D and Daggett V (1999) PrPc glycoform heterogeneity as a function of brain region: implications for selective targeting of neurons by prion strains. J. Neuropathol. Exp. Neurol. 58: 1000-1009

37. Kretzschmar HA, Prusiner SB, Stowring LE and DeArmond SJ (1986) Scrapie prion proteins are synthesized in neurons. Am. J. Pathol. 122: 1-5

38. Moser M, Colello RJ, Pott U, Oesch B (1995) Developmental expression of the prion protein gene in glial cells. Neuron 14: 509-517

39. Cashman NR, Loertscher R, Nalbantoglu J, Shaw I, Kascsak RJ, Bolton DC and Bendheim PE (1990) Cellular isoform of the scrapie agent protein participates in lymphocyte activation. Cell 61: 185-192

40. Manson J, West JD, Thomson V, McBride P, Kaufman MH and Hope J (1992) The prion protein gene: a role in mouse embryogenesis? Development 115: $117-122$

41. Prusiner SB, Fuzi M, Scott M, Serban D, Serban H, Taraboulos A, Gabriel JM, Wells GA, Wilesmith JW, Bradley R, et al. (1993) Immunologic and molecular biologic studies of prion proteins in bovine spongiform encephalopathy. J. Infect. Dis. 167: 602-613

42. Owen F, Poulter M, Lofthouse R, Collinge J, Crow TJ, Risby D, Baker HF, Ridley RM, Hsiao K and Prusiner SB (1989) Insertion in prion protein gene in familial Creutzfeldt-Jakob disease [letter]. Lancet 1: 51-52

43. Collinge J, Harding AE, Owen F, Poulter M, Lofthouse R, Boughey AM, Shah T and Crow TJ (1989) Diagnosis of Gerstmann-Straussler syndrome in familial dementia with prion protein gene analysis. Lancet 2: 15-17

44. Stockel J, Safar J, Wallace AC, Cohen FE and Prusiner SB (1998) Prion protein selectively binds copper(II) ions. Biochemistry 37: 7185-7193

45. Bendheim PE, Brown HR, Rudelli RD, Scala LJ, Goller NL, Wen GY, Kascsak RJ, Cashman NR and Bolton DC (1992) Nearly ubiquitous tissue distribution of the scrapie agent precursor protein. Neurology 42: 149-156

46. Yehiely F, Bamborough P, Da Costa M, Perry BJ, Thinakaran G, Cohen FE, Carlson GA and Prusiner SB (1997) Identification of candidate proteins binding to prion protein. Neurobiol. Dis. 3: $339-355$ 
47. Rieger R, Edenhofer F, Lasmezas $\mathrm{Cl}$ and Weiss S (1997) The human 37-kDa laminin receptor precursor interacts with the prion protein in eukaryotic cells [see comments]. Nat. Med. 3: 1383-1388

48. Martins VR, Graner E, Gacia-Abreu J, de Souza SJ, Mercadante AF, Veiga SS, Zanata SM, Neto VM and Brentani RR (1997) Complementary hydropathy identifies a cellular prion protein receptor [see comments]. Nat. Med. 3: $1376-$ 1382

49. Lee IY, Westaway D, Smit AF, Wang K, Seto J, Chen L, Acharya C, Ankener M, Baskin D, CooperC, Yao H, Prusiner SB and Hood LE (1998)Complete genomic sequence and analysis of the prion protein gene region from three mammalian species. Genome Res. 8: 1022-1037

50. Westaway D, Cooper C, Turner S, Da Costa M, Carlson GA and Prusiner SB (1994) Structure and polymorphism of the mouse prion protein gene. Proc. Natl. Acad. Sci. U.S.A. 91: 6418-6422

51. Sakaguchi S, Katamine S, Shigematsu K, Nakatani A, Moriuchi R, Nishida N, Kurokawa K, Nakaoke R, Sato H, Jishage K, et al. (1995) Accumulation of proteinase K-resistant prion protein $(\mathrm{PrP})$ is restricted by the expression level of normal PrP in mice inoculated with a mouse-adapted strain of the CreutzfeldtJakob disease agent. J. Virol. 69: 7586-7592

52. Sakaguchi S, Katamine S, Nishida N, Moriuchi R, Shigematzu K, Sugimoto T, Nakatni A, Kataoka Y, Houtani H, Shirabe S, Okada H, Hasegawa S, Myamoto T and Noda T (1996) Loss of cerebellar Purkinje Cells in aged mice homozygous for a disrupted PrP gene. Nature 380: 528-531

53. Nishida N, Tremblay P, Sugimoto T, Shigematsu K, Shirabe S, Petromilli C, Erpel SP, Nakaoke R Atarashi R, Houtani T, Torchia M, Sakaguchi S, DeArmond SJ, Prusiner SB and Katamine S (1999) A mouse prion protein transgene rescues mice deficient for the prion protein gene from purkinje cell degeneration and demyelination. Lab. Invest. 79: 689-697

54. Moore RC, Lee IY, Silverman GL, Harrison PM, Strome R, Heinrich C, Karunaratne A, Pasternak SH, Chishti MA, Liang Y, Mastrangelo P, Wang K, Smit AF, Katamine S, Carlson GA, Cohen FE, Prusiner SB, Melton DW, Tremblay P, Hood LE and Westaway D (1999) Ataxia in prion protein (PrP)deficient mice is associated with upregulation of the novel PrP-like protein doppel [In Process Citation]. J. Mol. Biol. 292: 797-817

55. Shmerling D, Hegyi I, Fischer M, Blattler T, Brandner S, Gotz J, Rulicke T, Flechsig E, Cozzio A, von Mering C, Hangartner C, Aguzzi A and Weissmann C (1998) Expression of amino-terminally truncated PrP in the mouse leading to ataxia and specific cerebellar lesions. Cell 93: 203-214

56. Weissmann C and Aguzzi A (1999) Perspectives: neurobiology. PrP's double causes trouble. Science 286: $914-915$

57. Hope J (1999) Spongiform encephalopathies. Breech-birth prions [news; comment]. Nature 402: 737, 739

58. Kurschner C, Morgan JI, Yehiely F, Bamborough P, Da Costa M, Perry BJ, Thinakarin G, Cohen FE, Carlson GA and Prusiner SB (1995) The cellular prion protein $(\mathrm{PrP})$ selectively binds to $\mathrm{Bcl}-2$ in the yeast two-hybrid system. Identification of candidate proteins binding to prion protein. Brain. Res. Mol. Brain. Res. 30: 165-168

59. Kurschner $C$ and Morgan Jl (1996) Analysis of interaction sites in homo- and heteromeric complexes containing Bcl-2 family members and the cellular prion protein. Brain. Res. Mol. Brain. Res. 37: 249-258

60. Bakhshi A, Jensen JP, Goldman P, Wright JJ, McBride OW, Epstein AL and Korsmeyer SJ (1985) Cloning the chromosomal breakpoint of $t(14 ; 18)$ human lymphomas: clustering around $\mathrm{JH}$ on chromosome 14 and near a transcriptional unit on 18. Cell 41: 899-906

61. Kuwahara C, Takeuchi AM, Nishimura T, Haraguchi K, Kubosaki A, Matsumoto Y, Saeki K, Yokoyama T, Itohara S and Onodera T (1999) Prions prevent neuronal cell-line death [letter]. Nature 400: 225-226

62. Pattison IH (1966) The relative suceptibility of sheep, goats and mice to two types of the goat scrapie agent. Res. Vet. Sci. 7: 207-212

63. Scott M, Foster D, Mirenda C, Serban D, Coufal F, Walchli M, Torchia M, Groth D, Carlson G, DeArmond SJ, et al.(1989) Transgenic mice expressing hamster prion protein produce species-specific scrapie infectivity and amyloid plaques. Cell 59: $847-857$

64. Prusiner SB, Scott M, Foster D, Pan KM, Groth D, Mirenda C, Torchia M, Yang SL, Serban D, Carlson GA, et al. (1990) Transgenic studies implicate interactions between homologous PrP isoforms in scrapie prion replication. Cell 63: $673-686$
65. Pattison IH and Millson GC (1961) Experimental transmission of scrapie to goats and sheep by the oral route. J. Comp. Pathol. 71: 171-176

66. Bruce ME, Fraser H, McBride PA, Scott JR and Dickinson AG (1992) The basis of strain variation in scrapie. In: Prusiner SB, Collinge J, Powell J anderton B, eds. Prion Diseases of Humans and Animals. New York, London: Ellis Horwood pp. $497-508$

67. Bessen RA, Marsh RF (1994) Distinct PrP properties suggest the molecular basis of strain variation in transmissible mink encephalopathy. J. Virol. 68: $7859-7868$

68. Telling GC, Parchi P, DeArmond SJ, Cortelli P, Montagna P, Gabizon R, Mastrianni J, Lugaresi E, Gambetti P and Prusiner SB (1996) Evidence for the conformation of the pathologic isoform of the prion protein enciphering and propagating prion diversity [see comments]. Science 274: 2079-2082

69. Safar J, Wille H, Itri V, Groth D, Serban H, Torchia M, Cohen FE and Prusiner SB (1998) Eight prion strains have PrP(Sc) molecules with different conformations [see comments]. Nat. Med. 4: 1157-1165

70. Carlson GA, Kingsbury DT, Goodman PA, Coleman S, Marshall ST, DeArmond S, Westaway D and Prusiner SB (1986) Linkage of prion protein and scrapie incubation time genes. Cell 46: 503-511

71. Dickinson AG, Meikle VM and Fraser $H$ (1968) Identification of a gene which controls the incubation period of some strains of scrapie agentin mice. J. Comp. Pathol. 78: 293-299

72. Hunter N, Hope J, McConnell I and Dickinson AG (1987) Linkage of the scrapieassociated fibril protein $(\mathrm{PrP})$ gene and Sinc using congenic mice and restriction fragment length polymorphism analysis. J. Gen. Virol. 68: 2711-2716

73. McGill IS and Wells GA (1993) Neuropathological findings in cattle with clinically suspect but histologically unconfirmed bovine spongiform encephalopathy (BSE). J. Comp. Pathol. 108: 241-260

74. Jakob A (1921) Über eigenartige Erkrankungen des Zentralnervensystems mit bemerkenswertem anatomischem Befunde. (Spastische PseudoskleroseEncephalomyelpathie mit disseminierten Degenerationsherden). Z. ges. Neurol. Psychiatr. 64: 147-228

75. Weber T and Aguzzi A (1997) The spectrum of transmissible spongiform encephalopathies. Intervirology 40: 198-212

76. Lantos PL (1992) From slow virus to prion: a review of transmissible spongiform encephalopathies. Histopathology 20: 1-11

77. Giese A, Brown DR, Groschup MH, Feldmann C, Haist I and Kretzschmar HA (1998) Role of microglia in neuronal cell death in prion disease. Brain Pathol. 8 : 449-457

78. Weber T, Otto M, Bodemer M and Zerr I (1997) Diagnosis of Creutzfeldt-Jakob disease and related human spongiform encephalopathies. Biomed. Pharmacother. 51: $381-387$

79. Will R, Ironside JW, Zeidler M, Cousens SN, Estibeiro K, Alperovitch A, Poser S Pocchiari M, Hofman A and Smith (1996) A new variant of Creutzfeldt-Jakob disease in the UK. Lancet 347: 921-925

80. Goldgaber D, Goldfarb LG, Brown P, Asher DM, Brown WT, Lin S, Teener JW, Feinstone SM, Rubenstein R, Kascsak RJ, et al. (1989) Mutations in familial Creutzfeldt-Jakob disease and Gerstmann-Straussler-Scheinker's syndrome. Exp. Neurol. 106: 204-206

81. Kretzschmar HA, Honold G, Seitelberger F, Feucht M, Wessely P, Mehraein $P$ and Budka H (1991) Prion protein mutation in family first reported by Gerstmann, Straussler and Scheinker [letter]. Lancet 337: 1160

82. Hsiao K, Baker HF, Crow TJ, Poulter M, Owen F, Terwilliger JD, Westaway D, Ott J and Prusiner SB (1989) Linkage of a prion protein missense variant to Gerstmann-Straussler syndrome. Nature 338: 342-345

83. Aguzzi A and Weissmann C (1996) Sleepless in Bologna: transmission of fatal familial insomnia. Trends Microbiol. 4: 129-131

84. Lantos PL, Bhatia K, Doey LJ, al-Sarraj S, Doshi R, Beck J and Collinge J (1997) Is the neuropathology of new variant Creutzfeldt-Jakob disease and kuru similar? [letter]. Lancet 350: 187-188

85. Brown P (1998) Transmission of spongiform encephalopathy through biological products. Dev. Biol. Stand. 93: 73-78

86. Belay ED (1999) Transmissible spongiform encephalopathies in humans Annu. Rev. Microbiol. 53: 283-314

87. Powell Jackson J, Weller RO, Kennedy P, Preece MA, Whitcombe EM and Newsom Davis J (1985) Creutzfeldt-Jakob disease after administration of human growth hormone. Lancet 2: 244-246 
88. Hegde RS, Mastrianni JA, Scott MR, DeFea KA, Tremblay P, Torchia M, DeArmond SJ, Prusiner SB and Lingappa VR (1998) A transmembrane form of the prion protein in neurodegenerative disease. Science 279: 827-834

89. Hegde RS, Tremblay P, Groth D, DeArmond SJ, Prusiner SB and Lingappa VR (1999) Transmissible and genetic prion diseases share a common pathway of neurodegeneration [see comments]. Nature 402: 822-826

90. Brandner S, Raeber A, Sailer A, Blattler T, Fischer M, Weissmann C and Aguzzi $A(1996)$ Normal host prion protein (PrPC) is required for scrapie spread within the central nervous system. Proc. Natl. Acad. Sci. U.S.A. 93: 13148-13151

91. Blättler T, Brandner S, Raeber AJ, Klein MA, Voigtländer T, Weissmann C and Aguzzi A (1997) PrP-expressing tissue required for transfer of scrapie infectivity from spleen to brain. Nature $389: 69-73$

92. Kimberlin RH and Walker CA (1989) The role of the spleen in the neuroinvasion of scrapie in mice. Virus. Res. 12: 201-211

93. Hill AF, Zeidler M, Ironside J and Collinge J (1997) Diagnosis of new variant Creutzfeldt-Jakob disease by tonsil biopsy. Lancet 349: 99

94. Klein MA, Frigg R, Flechsig E, Raeber AJ, Kalinke U, Bluethmann H, Bootz F, Suter M, Zinkernagel RM and Aguzzi A (1997) A crucial role for B cells in neuroinvasive scrapie. Nature 390: 687-690

95. Kitamoto T, Muramoto T, Mohri S, Dohura K and Tateishi J (1991) Abnormal isoform of prion protein accumulates in follicular dendiritic cells in mice with Creutzfeldt-Jakob disease. J. Virol. 65: 6292-6295

96. Montrasio F, Frigg R, Glatzel M, Klein MA, Mackay F, Aguzzi A and Weissmann $C$ (2000) Impaired prion replication in spleen and delayed neuroinvasion in mice lacking functional follicular dendritic cells. Science 288: 1257-1259

97. Klein MA, Frigg R, Raeber AJ, FlechsigE, Hegyi I, Zinkernagel RM, Weissmann C and Aguzzi A (1998) PrP expression in B lymphocytes is not required for prion neuroinvasion. Nat. Med. 4: 1429-1433

98. Kimberlain RH, Field HJ and Walker CA (1983) Pathogenesis of mouse scrapie: evidence for spread of infection from central to peripheral nervous system. J. Gen. Virol. 64: 713-716

99. Beekes M, Baldauf E and Diringer H (1996) Sequential appearance and accumulation of pathognomonic markers in the central nervous system of hamsters orally infected with scrapie. J. Gen. Virol. 77: 1925-1934

100. Diedrich JF, Bendheim PE, Kim YS, Carp RI and Haase AT (1991) Scrapieassociated prion protein accumulates in astrocytes during scrapie infection. Proc. Natl. Acad. Sci. U.S.A. 88: $375-379$
101. Chung YL, Williams A, Beech JS, Williams SC, Bell JD, Cox IJ and Hope J (1995) MRI assessment of the blood-brain barrier in a hamster model of scrapie. Neurodegeneration 4: 203-207

102. Wisniewski HM, Lossinsky AS, Moretz RC, Vorbrodt AW, Lassmann H and Carp RI (1983) Increased blood-brain barrier permeability in scrapie-infected mice. J. Neuropathol. Exp. Neurol. 42: 615-626

103. Raeber AJ, Race RE, Brandner S, Priola SA, Sailer A, Bessen RA, Mucke L, Manson J, Aguzzi A, Oldstone MB, Weissmann C and Chesebro B (1997) Astrocyte-specific expression of hamster prion protein (PrP) renders PrP knockout mice susceptible to hamster scrapie. EMBO J. 16: 6057-6065

104. Kreutzberg GW (1996) Microglia: a sensor for pathological events in the CNS. Trends Neurosci. 19: 312-318

105. Brown DR, Schmidt B and Kretzschmar HA (1996) Role of microglia and host protein in neurotoxicity of a prion protein fragment. Nature $380: 345-347$

106. Farquhar C, Dickinson A and Bruce M (1999) Prophylactic potential of pentosan polysulphate in transmissible spongiform encephalopathies [letter] [see comments]. Lancet 353: 117

107. Caughey WS, Raymond LD, Horiuchi M and Caughey B (1998) Inhibition of protease-resistant prion protein formation by porphyrins and phthalocyanines. Proc. Natl. Acad. Sci. U.S.A. 95: 12117-12122

108. Priola SA, Raines A and Caughey WS (2000) Porphyrin and phthalocyanine antiscrapie compounds [see comments]. Science 287: 1503-1506

109. Soto C, Kascsak RJ, Saborio GP, Aucouturier P, Wisniewski T, Prelli F, Kascsak R, Mendez E, Harris DA, Ironside J, Tagliavini F, Carp RI and Frangione B (2000) Reversion of prion protein conformational changes by synthetic beta-sheet breaker peptides. Lancet 355: 192-197

110. Wickner RB (1994) [URE3] as an altered URE2 protein: evidence for a prion analog in Saccharomyces cerevisiae. Science 264: 566-569

111. Sondheimer $N$ and Lindquist $S$ (2000) Rnq1: an epigenetic modifier of protein function in yeast. Mol. Cell. 5: 163-172

112. LiL and LindquistS (2000) Creating a protein-based element of inheritance [see comments]. Science 287: 661-664

113. Ma J and LindquistS (1999) De novo generation of a PrPSc-like conformation in living cells. Nat. Cell. Biol. 1: 358-361 